\title{
Notícia sobre a Sociedade Internacional de Platonistas
}

\author{
Carlinda Fragale Pate Nuñez
}

Universidade de Santa úrsila - RJ

O IX Congresso da F. I. E. C. (Federação Internacional de Estudos Clássicos) e o II SYMPOSIUM PLATONICUM, ocorridos em Pisa e Perugia, respectivamente, de 24/08 a 06/09 passados, constituíram acontecimentos em muitos sentidos fecundos.

$\bar{A}$ parte o fato de eventos desta natureza sempre oportunizarem o contato com especialistas renomados e providenciarem uma ocasião favorável ao intercâmbio e atualização bibliográfico-acadêmicos, teve lugar, durante o segundo, a criação da Sociedade Internacional de Platonistas.

Esta Sociedade, fundada na cidade histórica de Bevagna, tem como objetivos fundamentais: 1) organizar os próximos SYMPOSIA PLATONICA; 2) publicar as atas dos simpósios; e 3) confeccionar e difundir entre os membros da Sociedade um Boletim Bibliográfico anual com informações (fundamentalmente fornecidas pelos próprios membros) sobre trabalhos, já publicados ou em vias de publicação, acerca de Platão, em todo o mundo.

Além dos Membros Fundadores (aqueles que participaram do II SYMPOSIUM PLATONICUM e que votaram na sessão constituinte da Sociedade), consideram-se: a) Membros de Pleno Direito todos os que tenham publicado, nos últimos quinze anos, ao menos um artigo relevante sobre Platão ou tenham defendido Tese de Doutorado (e/ou equivalente) referente ao Filósofo; b) Membros Associados - os que estejam realizando Tese de Doutorado (e/ou equivalente) sobre Platão. 
A taxa de inscrição para todos os Membros importa em US 30, ou £ 20 (libras esterlinas), válida por três anos, até o próximo SYMPOSIUM, a realizar-se em Bristol (Grã-Bretanha), em 1992, sobre o Político.

As solicitações de inscrição devem ser dirigidas diretamente ao presidente do Comitê Diretivo da Sociedade, Prof. CHRISTOPHER ROWE (Department of Classics and Archaelogy, University of Bristol, 11 Woodland Road, Bristol BS $81 \mathrm{~TB}$, England), a fim de que, posteriormente, sejam devolvidas as instruções acerca dos procedimentos para o pagamento da mencionada quota. Desde já, entretanto, é sabido que o Comitê levará em consideração os casos particulares em que se mostre difícil o pagamento em divisa estrangeira.

A Sociedade Internacional de Platonistas convida todos os interessados a que enviem diretamente ao endereço acima referido ou à representante nacional, a Prof a Carlinda F.P. Nuñez (Av. Rodolfo Amoedo, 418/102 - CEP 22620 - RJ; tel. (021) 399-9291), os dados completos de publicações sobre Platão, recentes ou no prelo, para efeito de inclusão no Boletim Bibliográfico que proximamente se pretende editar.

A fim de que a comunidade brasileira de platonistas se passa beneficiar do convênio ora celebrado, o Comitê Executivo da S. I. P. solicita a todos os Professores de Cultura Clássica que divulguem e levem ao conhecimento de helenistas que estejam trabalhando sobre Platão as notícias aqui veiculadas. Da mesma forma, a Prof ${ }^{\text {a }}$ Carlinda se coloca à disposição para quaisquer esclarecimentos. 